Short communication

\title{
Peatland restoration: Revegetating disturbed areas by means of fresh seed-containing hay application
}

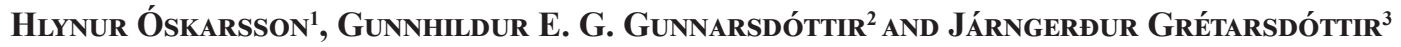 \\ ${ }^{1}$ Agricultural University of Iceland, Árleyni 22, 112 Reykjavik, Iceland. ${ }^{2}$ Soil Conservation Service, Arleyni 22, 112 \\ Reykjavik, Iceland. ${ }^{3}$ Icelandic Institute of Natural History, Urriðaholtsstrceti 6-8, 210 Garðabar \\ E-mail: hlynur@lbhi.is (correspondingauthor)
}

Keywords: Wetlands, species richness, bare soil, vegetation, rewetting.

\section{INTRODUCTION}

Peatlands were formerly a common feature of the Icelandic landscape, constituting around $20 \%$ of the vegetated surfaces of the island, but have since 1940 been subject to large-scale drainage (Arnalds et al. 2016). Currently it is estimated that more than $40 \%$ of the peatlands are fully drained and an additional $30 \%$ affected to some degree by the drainage (Óskarsson 1998, Arnalds et al. 2016). Peatland restoration has been practiced since 1996 (Garðarsson et al. 2006), for the most part at a very low rate, but has recently gained momentum and is expected to become broad-scale following an announcement by the Icelandic government to substantially increase peatland rewetting as a means of mitigating climate change (Umhverfisog auðlindaráðuneytið 2018). In Iceland the most common peatland restoration method has been, and is likely to remain, filling in of ditches with the previously excavated soil material (Áskellsdóttir 2017). This approach leaves a bare swathe of soil and currently does not involve any method for facilitating the re-establishment and succession of vegetation on the bare soil areas. A recent evaluation of the effectiveness of wetland restoration in Iceland found that in four out of five areas evaluated vegetation had not fully colonized the surface of the filled-in ditches four or more years after initiation of the restoration effort (Sigpórsdóttir 2018). In one of the areas, for example, only one fourth of the filled-in area was fully vegetated and one third of the surface was still bare soil five years after filling in the ditches. Furthermore, the study found that in the case of sloping fens, these bare soil areas are prone to soil erosion, and in the worst cases erosion opens up the ditches again and reduces the overall effectiveness of the restoration efforts (Sigpórsdóttir 2018). In light of these findings, there is a need for modification of the current practice to include some methodology for facilitating vegetation colonization of bare soil areas, and the need is urgent as restoration efforts are likely to increase substantially in the coming years.

A review paper by Kiehl et al. 2010 compared the effectiveness of several methods for establishing vegetation in restoration projects in both wetland and upland settings and found that the establishment was most successful when seeds, seed-containing plant material or soil are spread on bare ground. The fresh seed-containing hay method is one such technique that has been successfully used in various systems ranging from dry grasslands to floodplains and fens (Kiehl et al. 2010, Bischoff et al. 2018). In Iceland this method has been tried and successfully used in grassland ecosystems 
(Grétarsdóttir 2011, 2017), but until now has not been applied in wetland restoration projects and hence there is a lack of data on its usefulness under such conditions.

Here we present an assessment of the effectiveness of the fresh seed-containing hay method in facilitating vegetation establishment on bare soil swathes in a recently restored peatland in Southern Iceland.

\section{METHODS}

\section{Study site}

The study took place on a restored peatland site on the farm Skálholt, south Iceland (Figure 1). The peatland, a 15 ha former sloping mire, was rewetted in August 2016 by filling in the ditches with the originally excavated peat material. All in all, six $400 \mathrm{~m}$ long ditches were filled in, resulting in six $400 \times 20 \mathrm{~m}$ swathes of bare peat soil. Prior to rewetting, the vegetation present in the area was characterized by dryland species on the upper part of the slope and a mixture of dryland and wetland species on the lower part.

\section{Fresh seed-containing hay application}

In late September 2016 a total of 18 plots (9 control +9 treatments) were randomly placed

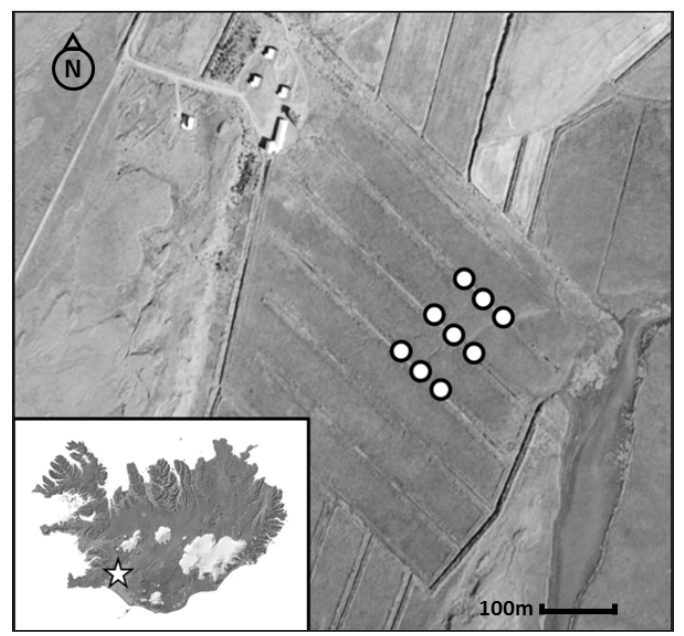

Figure 1. The rewetted peatland site at Skálholt. Circles indicate the approximate location of the nine control-treatment pairs. Small insert shows the location of the site within Iceland. within three of the six swathes of bare peat soil (three pairs of control/treatment plots per swathe). Each plot measured $3 \times 3 \mathrm{~m}$ equalling $9 \mathrm{~m}^{2}$. In determining the location of each plot pair along the swathes, care was taken to select a uniform area devoid of any pieces of turf or vegetation left over from the restoration procedure, as well as avoiding any obvious depressions with standing water.

Green seed-containing hay, including the moss layer, was harvested from vegetated areas adjacent to the bare soil swathes using a handheld spinning wire lawn mower. Each harvested donor plot was $9 \times 3 \mathrm{~m}$ corresponding to the combined area of the three receiving plots at each swathe; hence the area ratio between the donor plots and receiving plots was 1:1 (sensu Patzelt et al. 2001). The seed-hay from each of the three donor plots was split into three equal parts and spread over the randomly chosen receiving plots of the nine paired plots.

\section{Vegetation survey}

A vegetation survey was conducted at all 18 study plots in September 2017. Given that the vegetation was composed of herbs, grasses and moss, a $50 \times 50 \mathrm{~cm}$ quadrat with a $10 \times 10 \mathrm{~cm}$ grid was used in accordance with the guidelines of Cain and Castro (1959). To avoid edge effects, the outermost $50 \mathrm{~cm}$ of the plots were excluded, leaving $2.5 \times 2.5 \mathrm{~m}\left(6.25 \mathrm{~m}^{2}\right)$ of each plot available for measurements. Four randomly placed quadrats were surveyed in each plot, totalling 72 quadrats for the whole study. For each quadrat the presence or absence of each vascular plant species in the quadrat's grid cells was recorded, yielding a measure of each species frequency in the quadrat. Additionally the presence or absence (frequency) of bare soil, moss, and vascular plants in each quadrat's grid cells was recorded.

\section{Data analyses}

Statistical analyses were carried out using JMP (JMP ${ }^{\circledR}$, Version 13, SAS Institute Inc., Cary, NC, USA). Comparisons of the frequency of moss, frequency of vascular plants and overall number of vascular plants, between the 


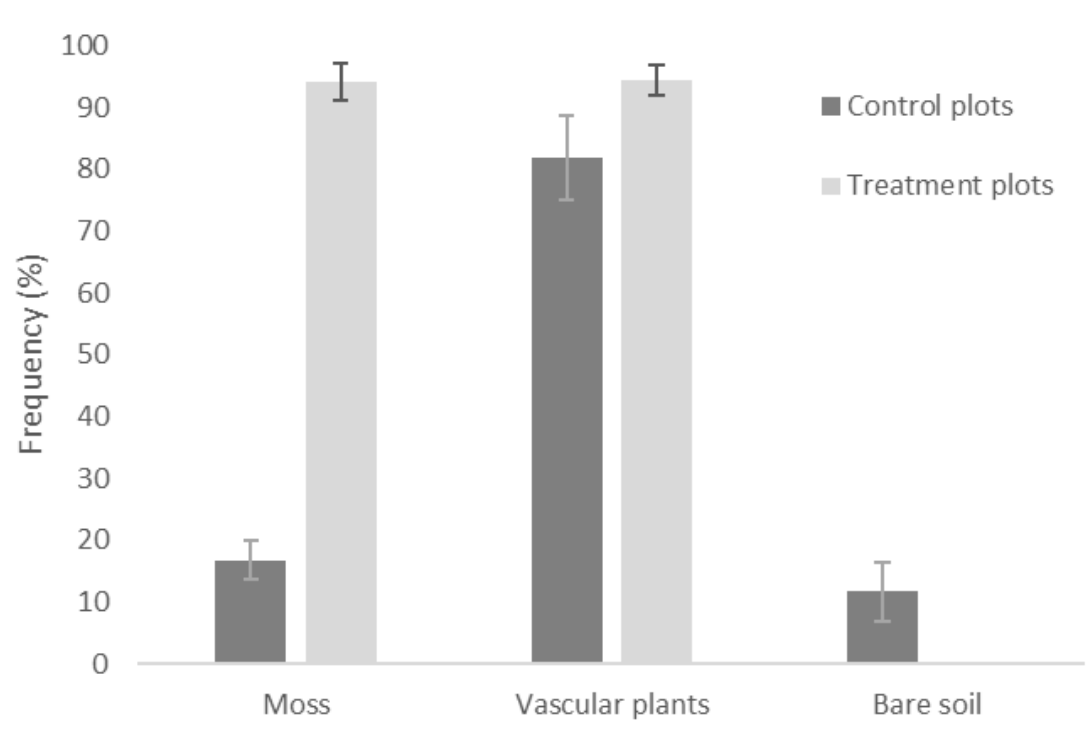

Figure 2. Comparison of the frequency of the three different cover classes between the control plots and the treatment plots. Vertical bars represent standard error.

control and treatment plots were accomplished using a conventional t-test. Comparisons of the frequency of individual vascular species between the control and treatment plots were performed using a Wilcoxon rank-sum test. The vascular species diversity of control and treatment plots was analysed according to the Shannon-Wiener diversity index (Spellerberg \& Fedor 2003).

\section{RESULTS}

All in all, 29 vascular plant species were found in the study plots, with the treatment plots harbouring all 29 species and the control plots 25 species (Table 1). Calculation of the ShannonWiener diversity index showed that the treatment plots were significantly more diverse (control: 1.60; treatment: $2.13 ; \mathrm{p}<0.005$ ).
Frequency of the three cover classes (moss; vascular species; bare soil) proved significantly different between the control and treatment plots (Figure 2). The frequency of both moss and vascular plant species was significantly higher in the treatment plots, with the difference in the frequency of moss being particularly pronounced (control: 17\%; treatment: 94\%; $\mathrm{p}<0.0001$ ). Sampling-frame grid-cells with only bare soil were not found within the treatment plots, whereas $12 \%$ of the control plot grid-cells had bare soil.

Out of the 25 vascular plant species found in both treatment and control plots, six proved to have a significantly higher frequency in the treatment plots, whereas no plants species exhibited significantly higher frequency in the control plots (Table 2).

Table 1. Comparison between the control and treatment plots of the total and average number of vascular plant species, Shannon-Wiener diversity index values and average frequency of moss.

\begin{tabular}{lcccc}
\hline & $\begin{array}{c}\text { Total no. } \\
\text { of species }\end{array}$ & $\begin{array}{c}\text { Average no. } \\
\text { of species }\end{array}$ & $\begin{array}{c}\text { Shannon-Wiener } \\
\text { diversity index }\end{array}$ & $\begin{array}{c}\text { Average moss } \\
\text { freq. }\end{array}$ \\
\hline Control plots & 25 & 11.1 & 1.60 & 16.8 \\
Treatment plots & 29 & 15.2 & 2.13 & 94.1 \\
\hline
\end{tabular}


Table 2. Vascular plant species that had a significantly higher frequency in the treatment plots compared to the control plots.

\begin{tabular}{lc}
\hline Species & $\mathrm{p}$-value \\
\hline Cardamine pratensis & 0.0011 \\
Comarum palustre & 0.0005 \\
Epilobium palustre & 0.0022 \\
Carex chordorrhiza & 0.0164 \\
Poa pratensis & 0.0223 \\
Festuca vivipara & 0.0301 \\
\hline
\end{tabular}

\section{DISCUSSION}

The science of ecosystem restoration is a relatively young discipline, but has matured considerably in recent decades (Zedler 2007; Nilsson et al. 2016). Through careful evaluation and modification of methods, ecosystem restoration practices are slowly developing (Nilsson et al. 2016). Assessing the outcome of restoration projects is critical to justify the use of restoration in general and to improve best practice (Wortley et al. 2013).

The recent evaluation of five peatland restoration projects in Iceland revealed that the methods traditionally used in peatland restoration need improvement (Sigpórsdóttir 2018). This is in particular true when it comes to the revegetating of disturbed areas. Inherent in the traditional practice is the assumption that bare soil swathes of filled-in ditches will, within a relatively short time, be colonized by vegetation already present in the rewetted area. The evaluation by Sigpórsdóttir (2018) showed that this is not the case in many instances, and hence it calls for amendment of the conventional practice.

Various methods have been used for facilitating vegetation establishment on restoration sites (Kiehl et al. 2010). Here we have presented the results from a trial of one such technique, the Transfer of fresh seedcontaining hay method, in a newly rewetted peatland in South Iceland. This method has been successfully applied in various environments and has even proved to have advantages in certain circumstances (Kiehl et al. 2010). In highly fragmented agricultural landscapes, for example, the transfer of fresh seed-containing hay has been shown to be a very efficient method to overcome dispersal limitation for plant species (Patzelt et al. 2001, Hölzel \& Otte 2003). Also, at restoration sites with slopes the hay acts as a mulch layer and provides effective erosion control (Kirmer \& Mahn 2001). Additionally, the method favours not only the transfer of vascular plants but also the introduction of mosses (Jeschke \& Kiehl 2006), as evidenced by our results.

These positive aspects of the fresh seedcontaining hay method, i.e. suitability on a slope, favouring the introduction of mosses and helping to overcome dispersal limits of plant species, render the method very appropriate for Icelandic conditions. A disproportionally greater area of sloping peatlands has been drained in Iceland as compared to other peatland types (Óskarsson 1998) and hence a method that works well on slopes is of value. Moss is a prevalent component in most Icelandic ecosystems and should therefore be included in revegetation efforts. Lastly, in some parts of Iceland (e.g. the Southern lowlands) remaining wetlands are few and far apart, and thus restoration efforts need to ensure that limitations to wetland plant species dispersal be overcome. In the light of this, and given the positive outcome of our trial of the method, we recommend that current peatland restoration practices in Iceland be amended to include the Transfer of fresh seed-containing hay to facilitate the establishment of vegetation in disturbed areas.

\section{ACKNOWLEDGEMENTS}

The authors would like to thank the Skálholt Suffragan Bishopric for permission to conduct this study on the Skálholt grounds. Financial support for this study was provided by OR Reykjavik Energy, Iceland.

\section{REFERENCES}

Áskelsdóttir S 2017. Endurheimt votlendis 2016 [Wetland restoration 2016]. LR 2017/04, Gunnarsholt, Iceland, 11 p. [In Icelandic]. 
Arnalds O, Gudmundsson J, Oskarsson H, Brink SH \& Gisladottir FO 2016. Icelandic Inland Wetlands: Characteristics and Extent of Draining. Wetlands 36, 759-769.

https://doi.org/10.1007/s13157-016-0784-1

Bischoff A, Hoboy S, Winter N \& Warthemann

G 2018. Hay and seed transfer to re-establish rare grassland species and communities: How important are date and soil preparation? Biological Conservation 221, 182-189.

https://doi.org/10.1016/j.biocon.2018.02.033

Cain SA \& Castro GM de O 1959. Manual of Vegetation analysis. Harper, NY pp. 325-326.

https://doi.org/10.1126/science.131.3408.1218-b

Garðarsson A, Magnússon B, Porleifsson EÓ, Óskarsson H, Hilmarsson JÓ \& Lund NA 2006. Endurheimt votlendis 1996-2006 [Wetland restoration 1996-2006]. Landbúnaðarráðuneytið, [Report by the Ministry of Agriculture] Reykjavík, 27 pp. [In Icelandic].

Grétarsdóttir J 2011. Söfnun og dreifing á fræslægju [Using fresh seed-containing hay in revegetation projects]. In: Aradóttir AL \& Grétarsdóttir J (eds.) Endurheimt staðargróðurs á röskuðum hálendissvæðum. Rit LbhÍ 29, 15-50 [In Icelandic].

Grétarsdóttir J 2017. Uppgræðsla með innlendum gróðri - Lokaskýrsla [Revegetating erosion areas using local species - final report]. Rit LbhÍ 81, 45 pp. [In Icelandic].

Hölzel N \& Otte A 2003. Restoration of a speciesrich flood meadow by topsoil removal and diaspore transfer with plant material. Applied Vegetation Science 6, 131-140.

https://doi.org/10.1111/j.1654-109X.2003.tb00573.x

Jeschke M \& Kiehl K 2006. Auswirkung von Renaturierungs- und Pflegemaßnahmen auf die Artendiversität von Gefäßpflanzen und Kryptogamen in neu angelegten Kalkmagerrasen. Tuexenia 26, 223-242. [In German]

Kiehl K, Kirmer A, Donath TW, Rasran L \& Hölzel N 2010. Species introduction in restoration projects - Evaluation of different techniques for the establishment of semi-natural grasslands in Central and Northwestern Europe. Basic and Applied Ecology 11, 285-299.

https://doi.org/10.1016/j.baae.2009.12.004

Kirmer A \& Mahn E-G 2001. Spontaneous and initiated succession on unvegetated slopes in the abandoned lignite-mining area of Goitsche, Germany. Applied Vegetation Science 4, 19-27. https://doi.org/10.1111/j.1654-109X.2001.tb00230.x

Nilsson C, Aradottir AL, Hagen D, Halldórsson G, Høegh K, Mitchell RJ, Raulund-Rasmussen K, Svavarsdóttir K, Tolvanen A \& Wilson SD 2016. Evaluating the process of ecological restoration. Ecology and Society 21(1), 41. http://dx.doi.org/10.5751/ES-08289-210141

Óskarsson H 1998. Framræsla votlendis á Vesturlandi [Wetland draining in Western Iceland]. In: Ólafsson JS (ed.) Íslensk votlendi, verndun og nýting [Icelandic Wetlands, Protection and Utilization]. Háskólaútgáfan, University of Iceland, Reykjavik, pp. 121-129 [In Icelandic].

Patzelt A, Wild U \& Pfadenhauer J 2001. Restoration of wet fen meadows by topsoil removal: Vegetation development and germination biology of fen species. Restoration Ecology 9, 127-136. https://doi.org/10.1046/j.1526-100x.2001.009002127.x.

Sigpórsdóttir TB 2018. Sannprófun mótvægisaðgerða vegna vegaframkvæmda: Skilar endurheimt votlendis tilætluðum árangri? A Master's thesis from the University of Iceland, Reykjavik. 72 pp. [In Icelandic].

Spellerberg IF \& Fedor PJ 2003. A tribute to Claude Shannon (1916-2001) and a plea for more rigorous use of species richness, species diversity and the 'Shannon-Wiener' Index. Global Ecology \& Biogeography 12, 177-179. https://doi.org/10.1046/j.1466-822X.2003.00015.x.

Umhverfis- og auðlindaráouneytið 2018. Aðgerðaáætlun í loftslagsmálum 2018-2030 [Ministry for the Environment and Natural Resources, Climate Change Strategy 2018-2030]. Reykjavik. 45 pp. [In Icelandic].

Wortley L, Hero J-M \& Howes M 2013. Evaluating ecological restoration success: A review of the literature. Restoration Ecology 21, 537-543. https://doi.org/10.1111/rec.12028

Zedler JB 2007. Success: An Unclear, Subjective Descriptor of Restoration Outcomes. Ecological Restoration 25(3), 162-168. https://doi.org/10.3368/er.25.3.162

Manuscript received 16.03.2020 Accepted 30.04.2020 